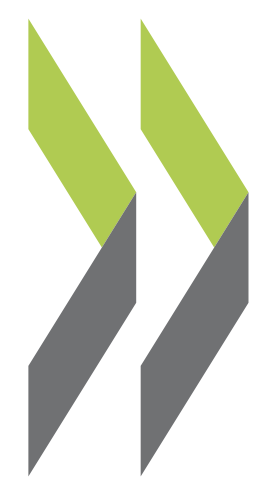

CELE Exchange, Centre for Effective Learning Environments $2009 / 10$

Sustainability Innovation in United Kingdom Schools

\section{Wayne Head,}

\section{Richard Buckingham}

https://dx.doi.org/10.1787/220784057722 


\section{Sustainability Innovation in} United Kingdom Schools

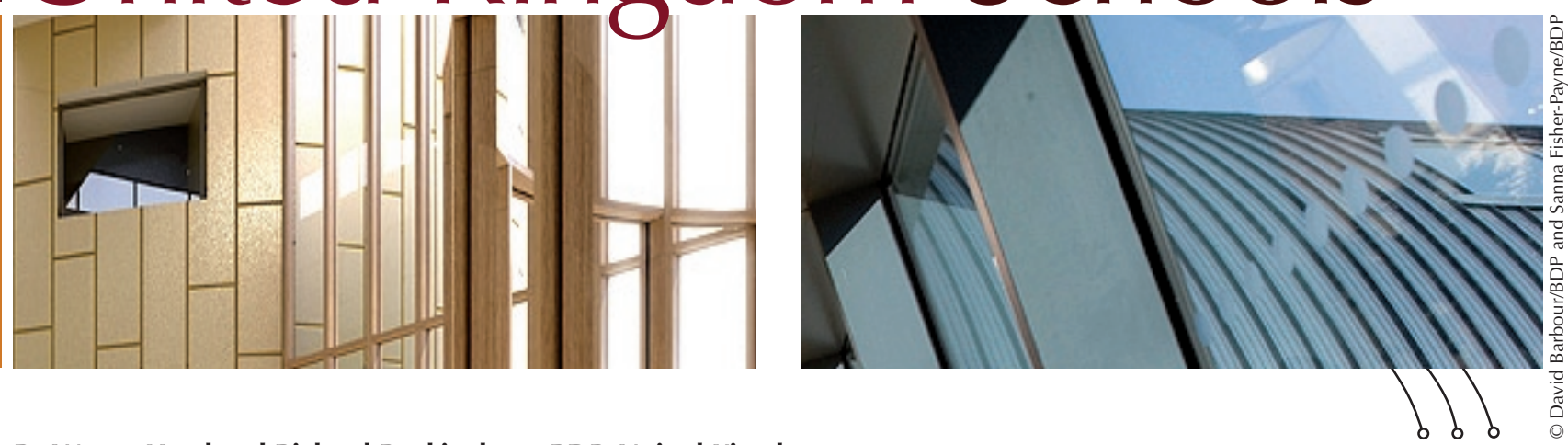

By Wayne Head and Richard Buckingham, BDP, United Kingdom

This article recommends approaches to take in designing sustainable educational environments. The authors present recent examples of UK school buildings that reduce carbon emissions and capitalise on renewable energy sources, and predict how schools will respond to energy needs in the future.

\section{SUSTAINABLE DESIGNS FOR LEARNING ENVIRONMENTS}

Architects and designers should look for opportunities to capture, re-use and recycle the energy, water, materials and waste resources available on site to minimise energy consumption and resources. The integration of buildings with their natural environment and the use of local bio-climate for environmental benefits is fundamental to the design.

Sustainability is measured by a "triple bottom line"; proposals need to be economically viable, socially equitable and environmentally sound. These three broad themes inter-relate throughout design, and optimising the synergies between them in an imaginative way is key to producing quality school buildings.

Sustainable thinking has played a key role in generating exemplary educational buildings and masterplans. Whether an innovative technology academy or a low energy school for students with learning difficulties, the overriding aim is to create socially progressive and resource efficient designs. The designs should provide inspirational learning environments shaped around people and deliver improved environmental performance in the present; they should also ensure the building has the ability to incorporate further renewable and low carbon solutions in the future, as the economic and environmental contexts change.

Sustainability should be a visible part of the educational environment. This can be achieved through the integration of living roofs, planting within the building, low-embodied energy and sustainable timber construction, and the use of renewable energy technologies.

\section{CURRENT EXEMPLARY BUILDINGS}

Leigh Technology Academy in Kent demonstrates an innovative sustainable design. The school specialises in information and communication technologies (ICT) with 1500 pupils located in four new colleges 
under one roof. The building's $\mathrm{CO}_{2}$ emissions were estimated to be $65 \%$ of the permissible limit set by the building regulations (Part L), based on the calculation methodology used by the UK Department for Education and Skills at the time of design. Leigh Technology Academy won three awards at the Building Services Awards 2008 including "Project of the Year" and "Best of the Best". Its sustainability credentials comprise the following:

- Passive cooling - Thermal mass is extensively used to eliminate the need to install mechanical cooling. In addition to the exposed ceilings (carefully co-ordinated with acoustic baffles and lighting to gain maximum radiant "coolth"), the floor void, risers and building structure are all used as heat sinks.

- Earth tubes - To further increase passive cooling, each of the four air handling units have 40m-long earth tubes drawing clean air (away from the busy road) under the school and up through concrete risers, thereby using ground source cooling to temper the air prior to introducing it into the teaching areas.

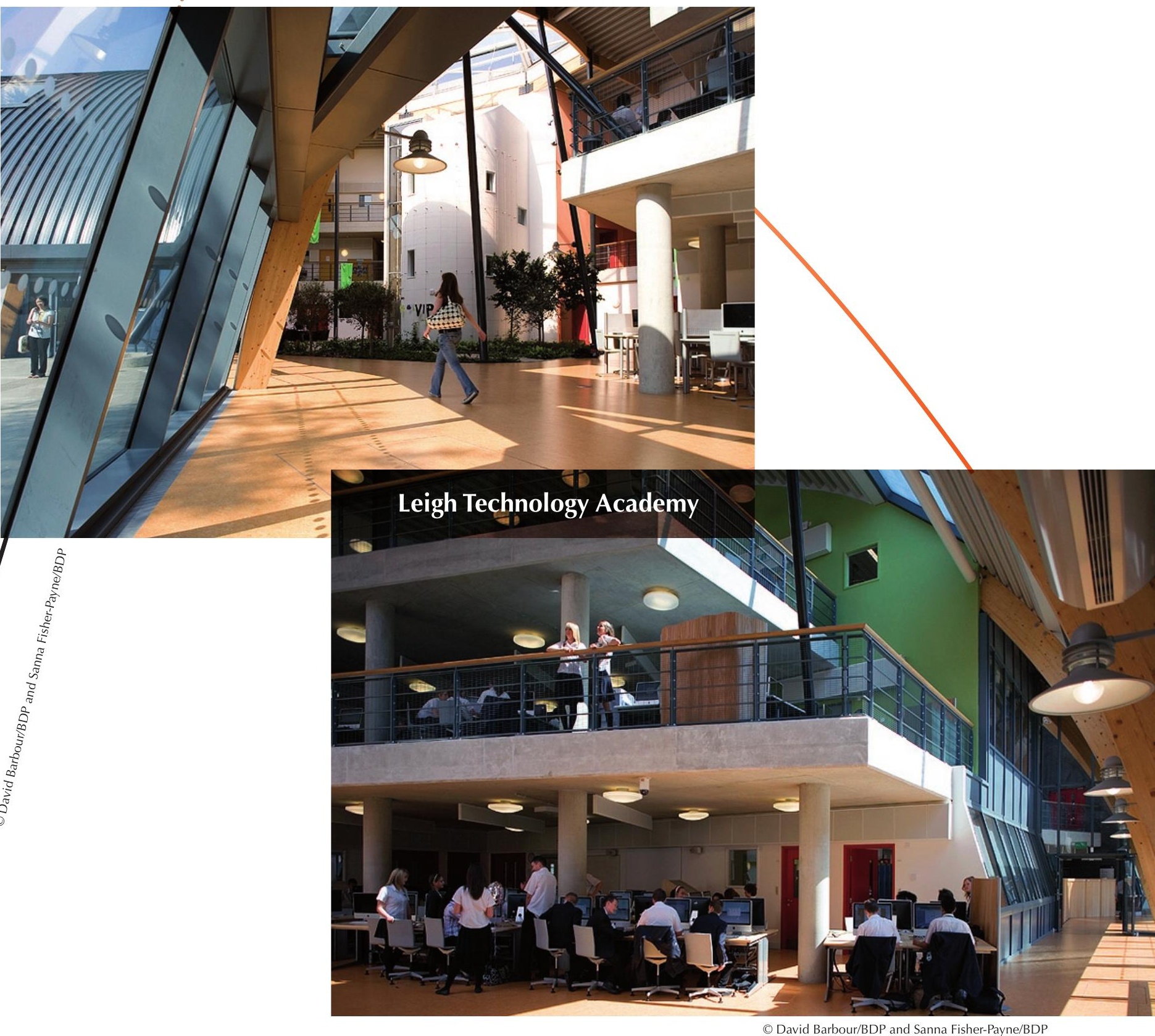




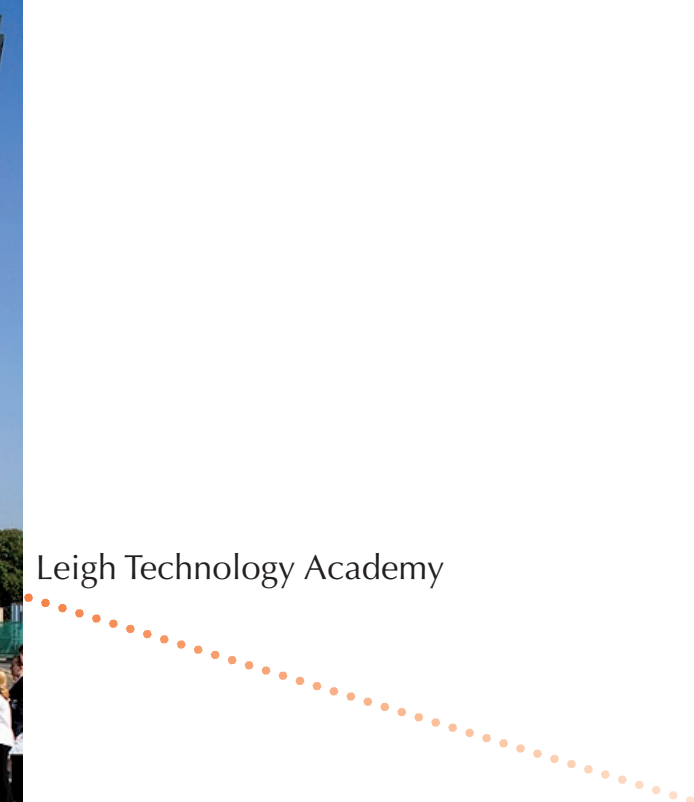

1 atede

- Wintergardens - These are key to passive stack ventilation in summer and reservoirs for heat reclamation in winter.

- Orientation - The building is designed to catch low angle sunlight in walkways where it can be captured and reused through central air handling units with heat exchangers, while avoiding summer sun angles and overheating. Classrooms predominantly face north to minimise the use of blinds and maximise the quality and quantity of daylight.

- Sealed façade - Due to surrounding external noise levels, the building needs to be acoustically sealed. However, rather than penalise the energy figures, the mechanical ventilation has been designed to maximise heat recovery and reduce heating energy.

A new school building in the London borough of Islington, to be completed in 2009, will generate $20 \%$ of its energy from on-site renewable energy installations. The $16000 \mathrm{~m}^{2}$ development will combine the Highbury Grove School and the Samuel Rhodes School, for users with mild learning difficulties. The new Highbury Grove School will provide, on the site of the existing school, a $21^{\text {st }}$ century learning environment for 1200 pupils thanks to the Building Schools for the Future (BSF) programme and a partnership between Islington Council and Transform Schools.

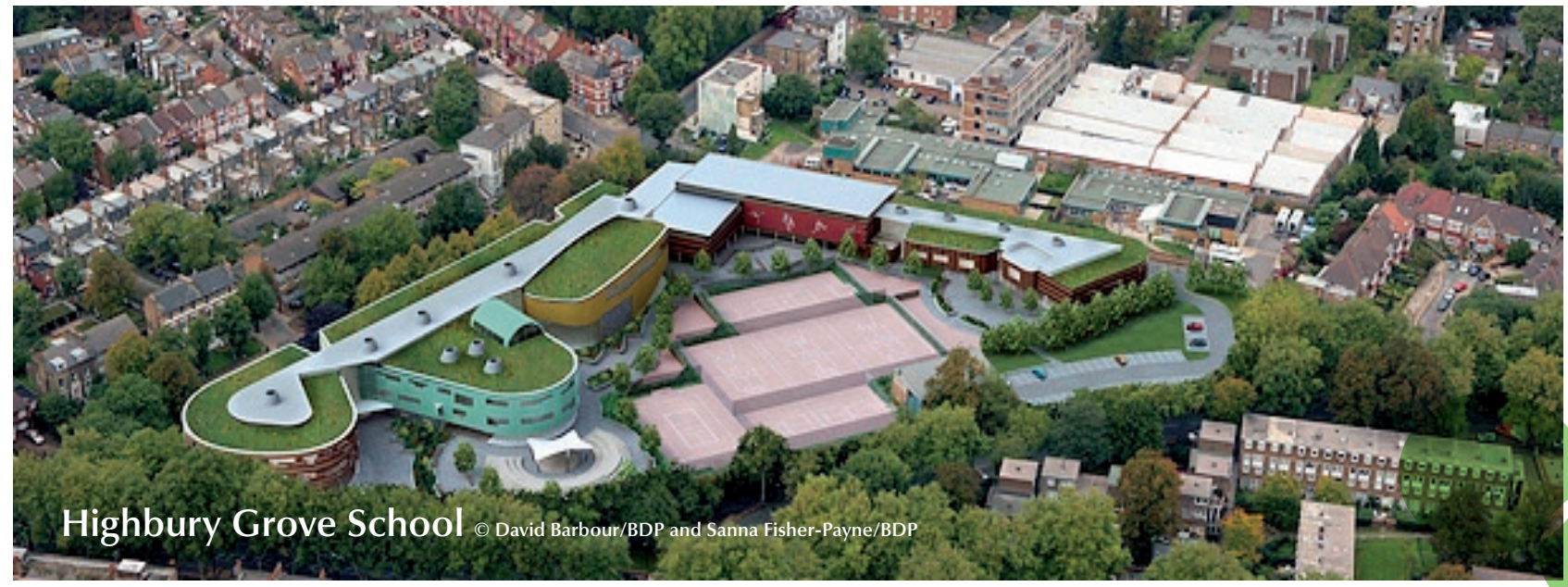




\section{GOING FORWARD}

In the future, public policy, resource restrictions and environmental considerations will further drive the resource efficiency of schools and the incorporation of renewable energy generation technologies. The move towards zero carbon new build schools will likely happen over the short term.

However, operating schools uses resources in other ways as well, such as transport, waste management, water use, food consumption and supply chains. A zero carbon school may emit no carbon from its building's energy use but have carbon implications elsewhere. Tackling these other resource consuming elements of school operation should form the next agenda for carbon reductions in schools.

These elements can be addressed through a combination of clever design and operational policies. The interface between design and operation should not be overlooked - design should enhance, rather than restrict, opportunities to deliver resource efficient operation.

In the United Kingdom, the government's commitment to achieving an 80\% carbon reduction target on 1990 levels by 2050 affords an excellent opportunity to deliver carbon negative buildings. Schools can capitalise on their physical and operational attributes to generate energy for use in other contexts and move towards a carbon negative position. Energy generated by their renewable technologies can be made available to the electricity grid and surrounding buildings when the school does not require it. This could be achieved through linking the schools to surrounding buildings to balance energy loads.

Schools generally operate during the day when domestic properties require less energy; conversely, in the early mornings, evenings and weekends when domestic properties require more energy, schools require less. Therefore, any district heating systems and CHP systems at the school site could be linked with other uses in order to balance energy loads, increase economic viability and provide for carbon reductions.

Other renewables such as photovoltaics and wind power could export electricity to the grid in the evenings, weekends and school holidays when power is not required for the school.

Historically, the link between design performance and operational performance has not always been appropriately considered. Going forward, the necessity to deliver low and zero carbon lifestyles as well as low and zero carbon buildings will forge a more integrated relationship between design and operation.

For more information, contact:

Wayne Head

Architect Director

$B D P$

16 Brewhouse Yard, Clerkenwell

London EC1V 4LJ

United Kingdom

Tel.: 44 (0)20 78128340

E-mail: wayne.head@bdp.com

www.bdp.com

Richard Buckingham

Head of Sustainability

$B D P$

16 Brewhouse Yard, Clerkenwell

London EC1V 4LJ

United Kingdom

www.bdp.com 


\section{ORGANISATION FOR ECONOMIC CO-OPERATION AND DEVELOPMENT}

The OECD is a unique forum where the governments of 30 democracies work together to address the economic, social and environmental challenges of globalisation. The OECD is also at the forefront of efforts to understand and to help governments respond to new developments and concerns, such as corporate governance, the information economy and the challenges of an ageing population. The Organisation provides a setting where governments can compare policy experiences, seek answers to common problems, identify good practice and work to co-ordinate domestic and international policies.

The OECD member countries are: Australia, Austria, Belgium, Canada, the Czech Republic, Denmark, Finland, France, Germany, Greece, Hungary, Iceland, Ireland, Italy, Japan, Korea, Luxembourg, Mexico, the Netherlands, New Zealand, Norway, Poland, Portugal, the Slovak Republic, Spain, Sweden, Switzerland, Turkey, the United Kingdom and the United States. The Commission of the European Communities takes part in the work of the OECD.

OECD Publishing disseminates widely the results of the Organisation's statistics gathering and research on economic, social and environmental issues, as well as the conventions, guidelines and standards agreed by its members.

This work is published on the responsibility of the Secretary-General of the OECD. The opinions expressed and arguments employed herein do not necessarily reflect the official views of the Organisation or of the governments of its member countries.

You can copy, download or print OECD content for your own use, and you can include excerpts from OECD publications, databases and multimedia products in your own documents, presentations, blogs, websites and teaching materials, provided that suitable acknowledgment of OECD as source and copyright owner is given. All requests for public or commercial use and translation rights should be submitted to rights@oecd.org. Requests for permission to photocopy portions of this material for public or commercial use shall be addressed directly to the Copyright Clearance Center (CCC) at info@copyright.com or the Centre français d'exploitation du droit de copie (CFC) at contact@cfcopies.com. 